\title{
Adaptasi Legum Pohon yang Diinokulasi dengan Fungi Mikoriza Arbuskular (FMA) Saat Cekaman Kekeringan
}

\author{
Adaptation of Tree Legume Inoculated with Arbuscular Mycorrhiza Fungi (AMF) \\ in Drought Stress
}

\author{
S. Sowmen ${ }^{1}$, L. Abdullah ${ }^{2}$, P.D.M.H. Karti ${ }^{2}$, D. Soepandi ${ }^{3}$ \\ ${ }^{1}$ Fakultas Peternakan Universitas Andalas Padang Kampus Unand Limau Manis Padang, 25163 \\ ${ }^{2}$ Fakultas Peternakan Institut Pertanian Bogor Jl. Agatis Kampus IPB Darmaga Bogor, 16680 \\ ${ }^{3}$ Fakultas Pertanian Institut Pertanian Bogor Jl. Meranti Kampus IPB Darmaga Bogor, 16680 \\ email: simel.hanna@gmail.com \\ (Diterima: 2 September 2013; Disetujui: 27 Januari 2014)
}

\begin{abstract}
ABSTRAK
Penelitian ini bertujuan untuk mengevaluasi mekanisme adaptasi tanaman legum pohon (Desmodium $s p$ dan Leucaena leucocephala) yang diinokulasi dengan fungi mikoriza arbuskular (FMA) terhadap cekaman kekeringan. Penelitian ini dirancang menggunakan Rancangan Acak Lengkap (RAL) pola faktorial, faktor pertama adalah inokulasi FMA (tanpa inokulasi dan inokulasi dengan FMA), faktor ke-2 adalah kekeringan (disiram setiap hari, cekaman kekeringan). Parameter penelitian ini adalah kandungan air tanah (KAT), potensial air daun (PAD), kadar air relatif daun (KARD), dan bobot kering tanaman. Data dianalisis dengan analisis sidik ragam (ANOVA), jika terdapat pengaruh terhadap peubah yang diukur maka akan dilanjutkan dengan uji Duncan Multiple Range Test (DMRT). Tidak ada pengaruh interaksi $(\mathrm{P}>0,05)$ antara inokulasi FMA dengan cekaman kekeringan terhadap KAT, KARD, dan bobot kering tanaman ke-2 jenis legum pohon. Cekaman kekeringan menurunkan KAT, PAD, KARD dan bobot kering total pada tanaman legum pohon.
\end{abstract}

Kata kunci: legum, cekaman kekeringan, fungi mikoriza arbuskular (FMA)

\section{ABSTRACT}

This research was conducted to evaluate the adaptation mechanisms of tree legume (Desmodium sp and Leucaena leucocephala) which inoculated with mycorrhiza on drought stress. This experiment used factorial completely randomized design. The first factor was AMF (Arbuscular Mycorrhiza Fungi) inoculation (no mycorrhiza and with mycorrhiza), the second factor was drought (optimum watering and drought stress). Physiological and agronomical parameters consisted of soil water content (SWC), leaf water potential (LWP), leaf relative water content (LRWC), and plant dry weight. Data were analyzed by analysis of varian (ANOVA) and differences between treatments were tested by Duncan Multiple Range Test (DMRT). There was no significant interaction $(P>0.05)$ between AMF inoculation and drought treatment about SWC, LRWC, and plant dry weight for all tree legume. Drought stress decreased SWC, LWP, LRWC, and total dry weight of tree legume.

Keywords: legume, drought stress, Arbuscular Mycorrhiza Fungi

\section{PENDAHULUAN}

Produktivitas ternak terutama ruminansia sangat tergantung pada ketersediaan hijauan pakan sebagai pakan utama bagi ternak tersebut. Ketersediaan hijauan sangat dipengaruhi oleh musim terutama musim kemarau karena pada saat itu hijauan menjadi berkurang dan sulit didapatkan. Hal ini dapat terjadi karena pada saat kemarau kondisi air 
tanah menjadi defisit sehingga dapat menghambat pertumbuhan dan perkembangan tanaman. Defisit air atau cekaman kekeringan merupakan salah satu faktor penghambat produktifitas tanaman (Liu et al., 2011).

Cekaman kekeringan dapat menyebabkan perubahan fisiologis dan biokimia pada tanaman. Perubahan ini bertujuan untuk menyimpan air melalui tingginya osmotik eksternal dan memelihara aktifitas fotosintesis, dengan mengurangi pembukaan stomata untuk mengurangi kehilangan air (Kumar et al., 2011). Cekaman kekeringan pada tanaman dapat menurunkan bobot kering tajuk dan akar (El Tayeb dan Ahmed, 2010), potensial air (Sanchez et al., 2004), dan kandungan air relatif daun (Uzilday et al., 2012; Zhou et al., 2011).

Salah satu alternatif yang dapat dilakukan untuk mengatasi cekaman kekeringan adalah dengan pemanfaatan Fungi Mikoriza Arbuskular (FMA). Auge (2001) menjelaskan bahwa mikoriza dapat mempengaruhi keseimbangan air pada tanaman sehingga dapat meningkatkan ketahanan tanaman terhadap kekeringan. Beberapa penelitian tentang pemanfaatan FMA saat kekeringan terhadap tanaman pakan juga telah dilakukan yaitu pada rumput Setaria splendida Stapf (Karti, 2004), Gliricidia sepium dan Leucaena leucocephala (Fagbola et al., 2001), dan Alfalfa (Djebali et al., 2010). Namun sampai sekarang masih sedikit informasi terkait dengan mekanisme adaptasi legum pakan terutama legum pohon dalam menghadapi cekaman kekeringan.

Berdasarkan permasalahan di atas, dilakukan penelitian yang bertujuan untuk mengetahui mekanisme adaptasi dari 2 jenis legum pohon pada fase pertumbuhan awal terhadap cekaman kekeringan.

\section{METODE}

\section{Tempat Penelitian}

Penelitian ini dilaksanakan di Rumah Kaca Agrostologi, Fakultas Peternakan IPB, Rumah Kaca University Farm, Cikabayan IPB, Laboratorium Agrostologi Fakultas Peternakan IPB, Laboratorium Nutrisi Ternak
Perah IPB, dan Laboratorium Fisiologi Stress, Puslit Biologi, LIPI Cibinong.

\section{Materi Penelitian}

Tanaman pakan yang digunakan dalam penelitian adalah 2 jenis tanaman leguminosa pohon yang umum digunakan sebagai pakan ternak di Indonesia, yaitu: Leucaena leucocephala dan Desmodium sp. Menggunakan tanah ultisol, Mycofer (mikoriza komersial yang mengandung G. margarita dan G. manihotis) dari Laboratorium bioteknologi kehutanan, PAU IPB, serta bahanbahan untuk analisa kadar air tanah, kadar air relatif daun, dan lain-lain.

\section{Pelaksanaan Penelitian}

Pelaksanaan penelitian ini dimulai dengan mempersiapkan media tanam menggunakan tanah ultisol dan pupuk kandang dengan perbandingan 9: 1, tanah sebanyak 4,5 $\mathrm{kg}$ dan pupuk kandang 0,5 kg. Bibit tanaman legum pakan yang telah disiapkan disemai terlebih dahulu, ditumbuhkan sampai berumur 1 bulan. Selanjutnya tanaman legum pakan dipindahkan ke dalam pot kapasitas $5 \mathrm{~kg}$ media tanam. Khusus untuk perlakuan dengan mikoriza, pada media tanam ditambahkan Mycofer sebanyak 20 gram $\quad( \pm 1$ sendok makan) pada lubang tanam kemudian baru tanaman dipindahkan. Setiap lubang tanam ditanami dengan 2 individu tanaman legum pakan.

Tanaman dipelihara selama \pm 1 bulan. Pemeliharaan dilakukan dengan menyiram tanaman dua hari sekali, membersihkan gulma yang tumbuh secara manual, dan pemupukan dengan NPK dilakukan pada 14 hari setelah tanaman dipindahkan ke dalam pot. Setelah tanaman tumbuh dengan baik selanjutnya dilakukan pemangkasan awal (trimming) untuk menyeragamkan tinggi tanaman. Satu minggu kemudian perlakuan cekaman kekeringan dimulai yaitu dengan tidak melakukan penyiraman sampai tanaman mati (untuk perlakuan cekaman kekeringan $=\mathrm{D}$ ), sedangkan untuk perlakuan disiram (W) dilakukan penyiraman 1 kali sehari yaitu pada pagi hari.

Sebelum perlakuan cekaman kekeringan dimulai, semua media tumbuh dalam pot disiram terlebih dahulu sampai tercipta 
kondisi jenuh. Kemudian pot diberi plastik mulsa yang dibentuk bulat dengan diameter $\pm 35 \mathrm{~cm}$ untuk menutupi permukaan pot agar tidak terjadi evaporasi, dan dilubangi di tengahnya sebagai ruang untuk tanaman. Plastik mulsa diselotip di sekeliling pot pada perlakuan cekaman kekeringan (D), dan pada perlakuan disiram (W) diberi sedikit celah yang tidak diselotip untuk memudahkan penyiraman. Perlakuan dimulai pada keesokan harinya dan dihitung sebagai hari ke-0.

Pengambilan sampel kadar air tanah, kadar air relatif daun, dan potensial air daun dilakukan per 4 hari dimulai sejak hari ke-0. Penyiraman pot untuk perlakuan W dilakukan setiap pagi hari, sedangkan untuk perlakuan D tidak dilakukan penyiraman sampai tanaman mencapai lethal point dan ini berarti perlakuan dihentikan. Selanjutnya tanaman dipotong (dipanen), dan dapat dilakukan pengambilan sampel tanaman untuk peubah bobot segar dan bobot kering tanaman.

\section{Peubah yang Diamati \\ Kadar air tanah / KAT (\%)}

Kadar air tanah diuji secara manual, yaitu dengan cara mengambil 5 gram sampel tanah segar (BS) yang diambil dari tanah pada kedalaman $20 \mathrm{~cm}$, kemudian dioven $105^{\circ} \mathrm{C}$ selama 24 jam. Kemudian timbang berat setelah dioven $(\mathrm{BO})$.

Kadar air tanah $=(\mathrm{BS}-\mathrm{BO}) / \mathrm{BO} \times 100 \%$

\section{Bobot kering akar, batang dan daun (g/pot)}

Setelah pemanenan, bagian tanaman seperti akar, batang dan daun segar dikeringkan pada suhu $70^{\circ} \mathrm{C}$ selama 48 jam, kemudian ditimbang sebagai bobot kering akar, batang dan daun.

\section{Potensial air daun (MPa)}

Sampel yang digunakan untuk pengukuran potensial air daun adalah daun segar tanaman legum pakan. Sampel diambil sekitar pukul 4 WIB dini hari dan langsung dimasukkan ke dalam cup WP4, ditutup dan dimasukkan ke dalam coolbox.

Potensial air daun pada kondisi tanpa cekaman dan cekaman kekeringan diuji menggunakan WP4 Dewpoint Potentio Meter, dengan cara: sampel daun segar dipotong menjadi beberapa bagian kemudian dimasuk- kan ke dalam cup WP4. Cup+sampel tanpa tutup dimasukkan ke dalam alat potensiometer dan tunggu sampai di layar menunjukkan nilai seperti ini: "Ts- $\mathrm{Tb}=-0,58$ ", kemudian tombol diputar ke posisi "read", tunggu hingga terdengar bunyi bip beberapa kali dan lampu keseimbangan menyala. Setelah angka menunjukkan posisi konstan, hasil yang tertera di layar WP4 dicatat sebagai nilai potensial air daun (ICT International, 2010).

\section{Kadar air relatif daun $(\%)$}

Nilai kadar air relatif daun diukur menggunakan metode Slatyer dan Barrs (1965) yang dimodifikasi, dengan cara: sampel daun segar ditimbang sehingga didapatkan berat segar (BS), kemudian dimasukkan ke dalam cup. Cup berisi sampel daun segar diberi aquadest sehingga seluruh permukaan daun terendam, ditutup dengan kertas saring, dan disimpan dalam suhu ruang selama 18-24 jam. Air yang masih tersisa dibuang dan sampel ditiriskan dengan tisu, ditimbang sehingga didapatkan berat turgid (BT). Kemudian sampel dioven pada suhu $60^{\circ}$ C selama $2 \times 24$ jam, ditimbang dan didapatkan berat kering (BK).

Nilai kadar air relatif daun (KARD) didapatkan dengan menggunakan perhitungan: $\mathrm{KARD}=(\mathrm{BS}-\mathrm{BK}) /(\mathrm{BT}-\mathrm{BK}) \times 100 \%$

\section{Rancangan Percobaan}

Percobaan ini menggunakan Rancangan Acak Lengkap pola faktorial dengan tiga ulangan. Faktor I adalah fungi mikoriza arbuskular (FMA): tanpa FMA (-AM) dan diinokulasi FMA (+AM), dan faktor II adalah kekeringan: disiram (W) dan cekaman kekeringan (D). Model matematis yang digunakan adalah menurut Steel dan Torrie (1995). Data yang diperoleh dianalisa dengan ANOVA, jika terdapat pengaruh terhadap peubah yang diukur, maka akan dilanjutkan dengan uji DMRT.

\section{HASIL DAN PEMBAHASAN}

\section{Kadar Air Tanah (KAT)}

Kadar air tanah (KAT) yang tersedia mempengaruhi pertumbuhan dan perkembangan tanaman. Apabila jumlah air yang ter- 
sedia di tanah tidak mencukupi bagi kebutuhan tanaman maka tanaman akan mengalami gangguan morfologi dan fisiologis sehingga pertumbuhan dan produktifitasnya akan terhambat, hal ini menyebabkan tanaman mengalami cekaman kekeringan. Tabel 1 menunjukkan pengaruh faktor penyiraman dan inokulasi mikoriza terhadap nilai kadar air tanah yang diuji.

Hasil penelitian menunjukkan bahwa perlakuan cekaman kekeringan menurunkan kadar air tanah berkisar antara $11-39 \%$ dibandingkan dengan kondisi tanpa cekaman. Hasil serupa juga diperoleh pada 4 jenis Turfgrasses (Midlawn bermudagrass, Prairie buffalograss, Meyer zoysiagrass dan Mustang tallfescue) yang mendapatkan bahwa kandungan air tanah pada hari ke-25 cekaman kekeringan mengalami penurunan sebanyak $78 \%$ (kandungan air tanah menjadi 8\%) pada Mustang tallfescue (Qian dan Fry, 1997).

Penurunan kandungan air tanah yang diuji akibat cekaman kekeringan diduga disebabkan pengambilan air tanah oleh akar karena permintaan tanaman, sementara ketersediaan air tanah tidak bertambah. Tanaman yang mengalami defisit air akan melakukan penyesuaian osmotik, diantaranya melalui peningkatan senyawa terlarut sehingga terjadi penurunan potensial osmotik sel dan memungkinkan air tanah dapat masuk ke dalam sel tanaman (Yoshiba et al., 1997; Taiz dan Zeiger, 2002).

\section{Potensial air daun (PAD)}

Aliran air terjadi dari potensial air yang tinggi ke potensial air yang rendah, saat potensial air tanah rendah akibat cekaman kekeringan maka tanaman akan merespon dengan lebih menurunkan potensial airnya sehingga air dari tanah dapat diserap oleh tanaman (Kramer dan Boyer, 1995). Rataan potensial air daun pada tanaman legum pohon fase pertumbuhan awal ditunjukkan pada Tabel 2 .

Tabel 2 menunjukkan bahwa secara umum perlakuan cekaman kekeringan menurunkan potensial air daun pada ke-2 jenis legum pohon fase pertumbuhan awal. Berbeda dengan pengaruh cekaman kekeringan, pemberian mikoriza dapat meningkatkan atau bahkan menurunkan potensial air daun yang diuji. Faktor mikoriza berpengaruh nyata pada L. leucocephala (pengamatan hari terakhir). Pada L. leucocephala, nilai potensial air daun tanaman yang diinokulasi dengan mikoriza lebih tinggi $29 \%$ dibandingkan dengan tanaman tanpa mikoriza. Hal ini diduga karena mikoriza cukup efektif dalam membantu penyerapan air tanah oleh akar sehingga tanaman tidak perlu menurunkan potensial air daun menjadi semakin negatif. Hasil serupa juga didapatkan oleh Sanchez Blanco et al. (2004) yaitu cekaman kekeringan pada tanaman Rosmarinus officinalis menurunkan potensial air daun pada tanaman yang diinokulasi dengan mikoriza dan juga tanaman tanpa mikoriza, tetapi penurunan ini lebih rendah pada tanaman tanpa mikoriza.

Faktor penyiraman berpengaruh nyata terhadap potensial air daun pada ke-2 jenis tanaman legum pohon. Nilai potensial air daun pada legum pohon yang diteliti mengalami penurunan seiring dengan semakin lamanya cekaman kekeringan. Hal ini ditunjukkan dengan nilai potensial air daun pada hari ke-8, dan ke-16 pengamatan berturut-turut dengan kisaran -1,1 MPa sampai -1,6 MPa dan -1,5 MPa sampai -9,7 MPa (Tabel 2). Pada hari terakhir pengamatan cekaman kekeringan terjadi penurunan potensial air daun sebesar 3-4x lipat dibandingkan dengan kondisi normal tanpa cekaman.

Beberapa penelitian juga mendapatkan nilai potensial air semakin negatif seiring dengan semakin lamanya durasi cekaman kekeringan seperti Ludlow (1989) yang memperoleh nilai potensial air daun lethal -12 MPa pada beberapa rumput C4. Fageria et al. (2010) menyatakan bahwa beberapa tanaman legum tropis dapat mentolerir penurunan potensial air daun sampai dengan $-20 \mathrm{MPa}$ pada saat mengalami cekaman kekeringan. Penurunan potensial air daun seiring penurunan kadar air tanah juga terlihat pada 4 species annual clover ( $T$. alexandrinum $L, T$. incarnatum $L, T$. resupinatum $L$, dan $T$. squarrosum L) (Lannuci et al., 2002), dan kedelai (Zhou et al., 2011) yang mengalami cekaman kekeringan. 
Tabel 1. Rataan kadar air tanah (\%) pada tanaman legum pohon fase pertumbuhan awal yang diinokulasi dan tanpa inokulasi mikoriza pada dua perlakuan penyiraman

\begin{tabular}{lccrrrrr}
\hline \multirow{2}{*}{ Jenis Tanaman } & \multicolumn{6}{c}{ Kadar air tanah $(\%)$} \\
\cline { 2 - 8 } & \multicolumn{6}{c}{ L. leucocephala } & \multicolumn{4}{c}{ Desmodium sp } \\
\hline Hari pengamatan & 8 & 16 & Akhir $^{(28)}$ & 8 & 16 & Akhir $^{(16)}$ \\
\hline Mikoriza: & 33,6 & 31,3 & 31,7 & 33,1 & 30,0 & 30,0 \\
-M & 34,4 & 30,7 & 33,5 & 30,3 & 27,4 & 27,4 \\
+M & & & & & & \\
Penyiraman: & 36,1 & $37,7^{\mathrm{a}}$ & $40,6^{\mathrm{a}}$ & $37,8^{\mathrm{a}}$ & $34,8^{\mathrm{a}}$ & $34,8^{\mathrm{a}}$ \\
W & 31,9 & $24,3^{\mathrm{b}}$ & $24,6^{\mathrm{b}}$ & $25,6^{\mathrm{b}}$ & $22,6^{\mathrm{b}}$ & $22,6^{\mathrm{b}}$ \\
D & &
\end{tabular}

Keterangan: ${ }^{\mathrm{a}, \mathrm{b}}$ pada kolom yang sama menunjukkan hasil yang berbeda nyata $(\mathrm{P}<0,05)$

$-\mathrm{M}=$ tanpa mikoriza, $+\mathrm{M}=$ diinokulasi FMA, $\mathrm{W}=$ disiram, $\mathrm{D}=$ tidak disiram.

Tabel 2. Rataan potensial air daun (MPa) pada tanaman legum pohon fase pertumbuhan awal yang diinokulasi dan tanpa inokulasi mikoriza pada dua perlakuan penyiraman

\begin{tabular}{lcccccc}
\hline \multirow{2}{*}{ Jenis Tanaman } & \multicolumn{6}{c}{ Potensial air daun (Mpa) } \\
\cline { 2 - 7 } Hari pengamatan & 8 & 16 & Akhir $^{(28)}$ & 8 & 16 & Akhir $^{(20)}$ \\
\hline Mikoriza: & & & & & & \\
-M & $-1,3$ & $-2,8$ & $-4,8^{\mathrm{b}}$ & $-2,1$ & $-5,3$ & $-4,7$ \\
+M & $-1,4$ & $-2,9$ & $-3,4^{\mathrm{a}}$ & $-0,8$ & $-5,9$ & $-4,8$ \\
Penyiraman: & & & & & & \\
W & $-1,1^{\mathrm{a}}$ & $-1,7^{\mathrm{a}}$ & $-1,9^{\mathrm{a}}$ & $-1,3$ & $-1,5^{\mathrm{a}}$ & $-1,3^{\mathrm{a}}$ \\
D & $-1,6^{\mathrm{b}}$ & $-4,0^{\mathrm{b}}$ & $-6,3^{\mathrm{b}}$ & $-1,6$ & $-9,7^{\mathrm{b}}$ & $-8,2^{\mathrm{b}}$ \\
\hline
\end{tabular}

Keterangan: ${ }^{\mathrm{a}, \mathrm{b}}$ pada kolom yang sama menunjukkan hasil yang berbeda nyata $(\mathrm{P}<0,05)$

$-\mathrm{M}=$ tanpa mikoriza, $+\mathrm{M}=$ diinokulasi FMA, $\mathrm{W}=$ disiram, $\mathrm{D}=$ tidak disiram

Saat cekaman kekeringan, kondisi air tanah yang defisit menyebabkan potensial air tanah mengalami penurunan dan hal ini harus diikuti oleh penurunan potensial air daun menjadi lebih negatif agar tercipta perbedaan gradient sehingga air masih dapat bergerak dari tanah yang kekeringan menuju daun (Blum, 2005). Pengaruh nyata interaksi faktor mikoriza dan penyiraman terhadap potensial air daun terjadi pada hari terakhir pengamatan cekaman kekeringan pada $L$. leucocephala (Gambar 1). Tanaman L. leucocephala yang tidak mengalami cekaman kekeringan, tidak mengalami penurunan potensial air daun baik pada tanaman yang diinokulasi dengan mikoriza maupun tanaman tanpa mikoriza. Saat tanaman ini mengalami cekaman kekeringan, terjadi penurunan potensial air daun yang cukup signifikan, tetapi penurunan potensial air daun ini lebih besar pada tanaman tanpa mikoriza dibandingkan dengan tanaman yang diinokulasi dengan mikoriza (Gambar 1).

Hasil ini membuktikan bahwa pada $L$. leucocephala mikoriza cukup efektif dalam membantu penyerapan air saat cekaman kekeringan, sehingga tanaman ini tidak perlu menurunkan potensial air daunnya menjadi semakin negatif. Mikoriza mempunyai hyfa yang dapat mengakses ruang pori tanah yang kecil yang tidak bisa dilakukan oleh akar maupun rambut akar tanaman induk sehingga dapat menyerap air tanah lebih banyak untuk mempertahankan aktifitas fisiologis selama ceKaman kekeringan (Christopher et al., 2008). Kandungan air relatif daun pada tanaman yang diinokulasi dengan mikoriza lebih rendah dibandingkan dengan tanaman tanpa 
mikoriza dan mekanisme terkait hal tersebut belum diketahui.

Berbeda dengan pengaruh faktor mikoriza, faktor penyiraman berpengaruh nyata pada setiap waktu pengamatan dari ke-2 jenis tanaman legum pohon, kecuali saat pengamatan hari ke-8 pada L. leucocephala. Hasil penelitian menunjukkan bahwa cekaman kekeringan menurunkan kadar air relatif daun dengan kisaran antara 52-76\% dibandingkan dengan tanaman yang tidak dicekam. Pada hari terakhir perlakuan cekaman kekeringan, penurunan kadar air relatif daun yang paling banyak $(76 \%)$ terjadi pada Desmodium sp. Penurunan kadar air relatif daun akibat cekaman kekeringan juga didapatkan oleh Da Costa dan Huang (2006), pada cekaman ke- keringan hari ke-15 terjadi penurunan kadar air relatif daun sebesar 68\% pada Creeping bentgrass dan $75 \%$ pada Velvet bentgrass dibandingkan dengan kondisi air optimal.

Kadar air relatif berhubungan dengan kemampuan untuk penyerapan air lebih banyak dari tanah dan kemampuan tanaman untuk mengontrol kehilangan air melalui stomata (Bayoumi et al., 2008). Pada Desmodium $s p$ cekaman kekeringan hari ke-8, terjadi penurunan KAR daun yang cukup signifikan, penurunan kadar air relatif daun $35,32 \%$ pada tanaman yang diinokulasi dengan mikoriza, dan $14,77 \%$ pada tanaman tanpa mikoriza dibandingkan dengan kondisi air optimal (Tabel 3).
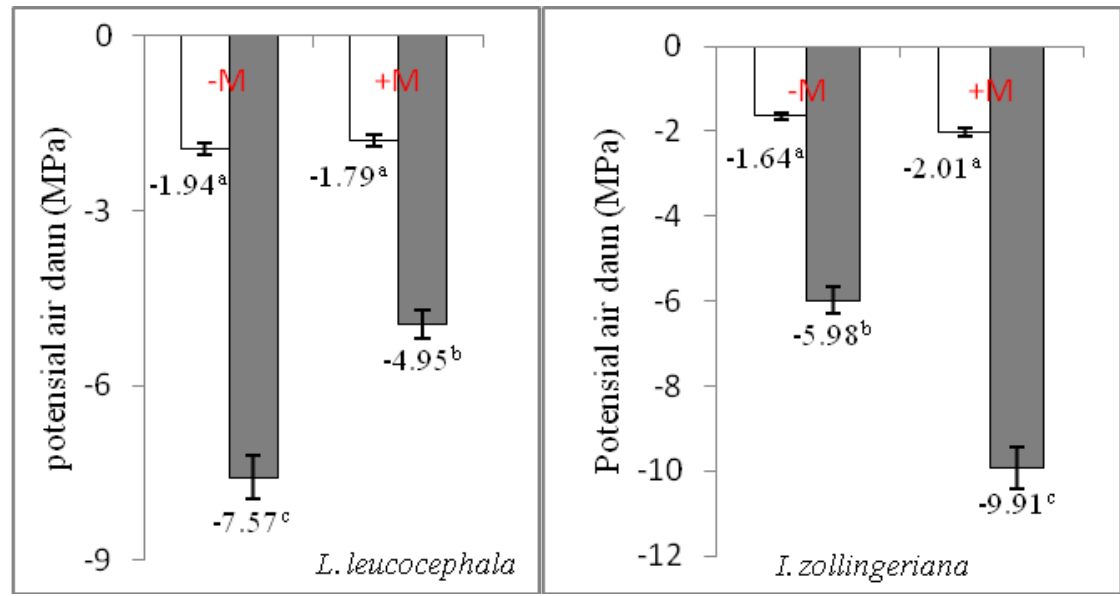

Gambar 1. Interaksi faktor penyiraman dan mikoriza terhadap potensial air daun (MPa) pada hari akhir pengamatan tanaman legum pohon fase pertumbuhan awal. $-\mathrm{M}=$ tanpa mikoriza, $+\mathrm{M}=$ mikoriza, $\square=$ disiram tiap hari (watering), $\mathbf{\square}=$ cekaman kekeringan $($ drought $)$.

Tabel 3. Rataan kadar air relatif (KAR) daun pada tanaman legum pohon fase pertumbuhan awal (\%) yang diinokulasi dan tanpa inokulasi mikoriza pada dua perlakuan penyiraman

\begin{tabular}{lcccccc}
\hline \multirow{2}{*}{ Jenis Tanaman } & \multicolumn{6}{c}{ Kadar air relatif daun (\%) } \\
\cline { 2 - 7 } & \multicolumn{5}{c}{ L. leucocephala } & \multicolumn{3}{c}{ Desmodium $s p$} \\
\hline Hari pengamatan & 8 & 16 & Akhir $^{(28)}$ & 8 & 16 & Akhir $^{(20)}$ \\
\hline Mikoriza: & 87,4 & 61,1 & 54,3 & $77,5^{\mathrm{a}}$ & 44,6 & 39,7 \\
-M & 87,0 & 61,7 & 52,8 & $67,9^{\mathrm{b}}$ & 43,4 & 36,9 \\
+M & & & & & & \\
Penyiraman: & 87,4 & $76,5^{\mathrm{a}}$ & $72,3^{\mathrm{a}}$ & $83,1^{\mathrm{a}}$ & $66,7^{\mathrm{a}}$ & $61,9^{\mathrm{a}}$ \\
W & 86,9 & $46,3^{\mathrm{b}}$ & $34,8^{\mathrm{b}}$ & $62,3^{\mathrm{b}}$ & $21,3^{\mathrm{b}}$ & $14,7^{\mathrm{b}}$ \\
D & &
\end{tabular}

Keterangan: ${ }^{\mathrm{a}, \mathrm{b}}$ pada kolom yang sama menunjukkan hasil yang berbeda nyata $(\mathrm{P}<0,05)$

$-\mathrm{M}=$ tanpa mikoriza,$+\mathrm{M}=$ diinokulasi FMA, $\mathrm{W}=$ disiram, $\mathrm{D}=$ tidak disiram 


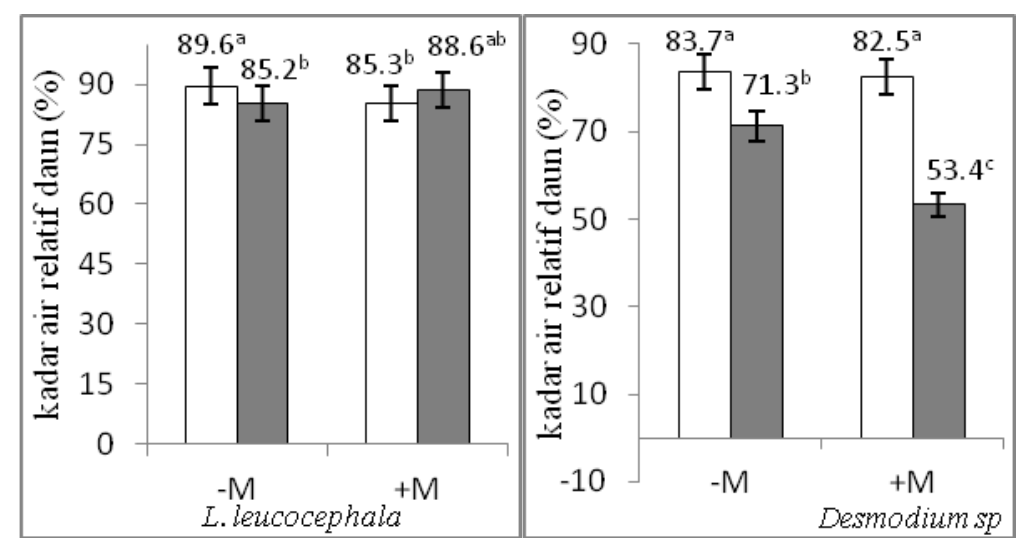

Gambar 2. Interaksi faktor penyiraman dan mikoriza terhadap kadar air relatif (KAR) daun tanaman legum pohon fase pertumbuhan awal pada hari ke-8.

$-\mathrm{M}=$ tanpa mikoriza, $+\mathrm{M}=$ mikoriza, $\square=$ disiram tiap hari (watering), $\mathbf{-}=$ cekaman kekeringan (drought).

Tabel 4. Rataan bobot kering total (g/pot) pada tanaman legum pohon fase pertumbuhan awal yang diinokulasi dan tanpa inokulasi mikoriza pada dua perlakuan penyiraman

\begin{tabular}{lcc}
\hline \multirow{2}{*}{ Jenis Tanaman } & \multicolumn{2}{c}{ BK total (g/pot) } \\
\cline { 2 - 3 } Mikoriza: & L.leucocephala & Desmodium $s p$ \\
-M & & \\
+M & 14,85 & $13,99^{\mathrm{b}}$ \\
Penyiraman: & 14,31 & $24,45^{\mathrm{a}}$ \\
W & & \\
D & $20,63^{\mathrm{a}}$ & $27,59^{\mathrm{a}}$ \\
\hline
\end{tabular}

Keterangan: ${ }^{\mathrm{a}, \mathrm{b}}$ pada kolom yang sama menunjukkan hasil yang berbeda nyata $(\mathrm{P}<0,05)$

$-\mathrm{M}=$ tanpa mikoriza,$+\mathrm{M}=$ diinokulasi FMA, $\mathrm{W}=$ disiram, $\mathrm{D}=$ tidak disiram

Saat cekaman kekeringan kadar air relatif daun perlakuan mikoriza lebih rendah $25 \%$ dibandingkan dengan tanaman tanpa mikoriza (Gambar 2). Hasil tersebut tidak menunjukkan mekanisme yang seharusnya dari mikoriza dalam membantu penyerapan air lebih efisien (KAR daun yang tinggi) saat tanaman mengalami cekaman kekeringan, dan mekanisme terkait hal tersebut belum diketahui.

L. leucocephala pada kondisi cekaman kekeringan, pemberian mikoriza justru meningkatkan kadar air relatif daun dibandingkan dengan tanaman tanpa mikoriza. Hasil ini mengindikasikan bahwa mikoriza cukup efektif dalam membantu penyerapan air karena adanya hyfa yang dapat menyebar luas di dalam tanah sehingga tanaman dapat mengambil air dari tanah relatif lebih banyak.

\section{Bobot kering tanaman (BK)}

Kondisi air yang defisit dapat mengganggu pertumbuhan dan perkembangan dari tanaman, sehingga berakibat pada penurunan bobot kering tanaman. Faktor mikoriza hanya berpengaruh terhadap bobot kering total pada Desmodium sp (Tabel 4). Pemberian mikoriza meningkatkan bobot kering total Desmodium $s p$ sebesar 74,8\% dibandingkan dengan tanaman tanpa mikoriza (Tabel 4).

Hasil tersebut menunjukkan bahwa mikoriza cukup efektif dalam membantu pertumbuhan tanaman sehingga menghasilkan bobot kering total lebih tinggi dibandingkan dengan tanaman tanpa mikoriza, dengan asumsi bahwa adanya hyfa mikoriza dapat membantu penyerapan air lebih efisien sehingga proses fotosintesis tidak begitu terganggu sehingga hasil fotosintesis dapat 
dimanfaatkan untuk pertumbuhan dan perkembangan tanaman dan dapat meningkatkan bobot kering total tanaman.Faktor penyiraman berpengaruh nyata terhadap bobot kering (BK) total pada ke-2 jenis tanaman legum pohon fase pertumbuhan awal. Perlakuan cekaman kekeringan menurunkan $\mathrm{BK}$ total dengan kisaran 26-61\% dibandingkan dengan BK total dalam kondisi normal tanpa cekaman (Tabel 4). Penurunan bobot kering total juga terjadi pada gandum (Jun Feng et al., 2010), kedelai (Hamim et al., 1996), Phaseolus vulgaris L. (Salwa dan Heba, 2011), dan Lepidium sativum L. (Khalil dan El Noemani, 2012) yang mengalami cekaman kekeringan.

\section{KESIMPULAN}

Respon tanaman terhadap cekaman kekeringan ditunjukkan dengan turunnya kadar air tanah, potensial air daun, kadar air relatif daun dan bobot kering total pada tanaman legum pohon. Inokulasi dengan FMA dapat membantu meningkatkan ketahanan kekeringan Desmodium sp pada fase pertumbuhan awal.

\section{DAFTAR PUSTAKA}

Augé, R. M. 2001. Water relations, drought and vesicular-arbuscular mycorrhizal symbiosis. Mycorrhiza 11: 3-42.

Bayoumi, T. Y., M. H. Eid, and E. M. Metwali. 2008. Application of hysiological and biochemical indices as a screening technique for drought tolerance in wheat genotypes. Afr. J. Biotech. 7 (14):2341-2352.

Blum, A. 2005. Drought resistance, water use efficiency and yield potential- are they compatible dissonant or mutually exclusive?. Australian Journal of Agricultural Research 56: 1159-1168.

Christopher, R.B., J. V. Tony, C. R. Boomsma and T. J. Vyn. 2008. Maize drought tolerance: Potential improvements through arbuscular mycorrhizal symbiosis?. Field Crops Research 108: 14-31.

Da Costa, M. and B. Huang. 2006. Osmotic adjustment associated with variation in Bentgrass tolerance to drought stress. J. Amer. Soc. Hort. Sci. 131(3): 338-344.

Djebali, N., S. Turki, M. Zid and M. R. Hajlouni. 2010. Growth and development responses of some legume species inoculated with a mycorrhiza-based biofertilizer. Agriculture on Biology Journal of North America. 1(5): 748754.

El Tayeb, M. A and N. L. Ahmed. 2010. Response of wheat cultivars to drought and salicylic acis. American-Eurasian Journal of Agronomy 3(1): 01-07.

Fagbola, O., O. Osonubi, K. Mulongoy and S. Odanfa. 2001. Effect of drought stress and arbuscular mycorrhiza on growth of Gliricidia sepium (Jacq). Walp, and Leucaena leucochepala (Lam.) de Wit in simulated eroded soil condition. Mycorrhiza 11(5):215-223.

Fageria, N. K., V. C. Baligar and C. A. Jones. 2010. Growth and Mineral Nutrition of Field Crops. Ch. 18. Forage. Third Ed. CRC Press.

Hamim, D. Sopandie dan M. Jusuf. 1996. Beberapa karakteristik morfologi dan fisiologi kedelai toleran dan peka terhadap cekaman kekeringan. Hayati 1:30-34.

ICT International. 2010. WP4 dewpoint potential meter. http://www.ictinternational.com.au/broc hures/WP4man22.pdf [20-04-2010].

Jun-Feng, S., M. X. Guo, J. R. Lian, P. Xiaobin, W. Y. Guo and C. X. Ping. 2010. Gene expression profiles of response to water stress at the jointing stage in wheat. Agricultural Sciences in China 9(3): 323-330.

Karti, P. D. M. H. 2004. Pengaruh pemberian cendawan Mikoriza Arbuskular 
terhadap pertumbuhan dan produksi rumput Setaria splendida Stapf yang mengalami cekaman kekeringan. Med. Pet. 27: 63-68.

Khalil, S. E., and A. A. El-Noemani. 2012. Effect of irrigation interval and exogenous proline application in improving tolerance of garden cress plant (Lepidium sativum L.) to water stress. J. App. Sci. Res. 8(1):157-167.

Kramer, P. J and J. S. Boyer. 1995. Water Relations of Plants and Soils. Academic Press Inc. US.

Kumar, R. R., K. Karajol and G. R. Naik. 2011. Effect of polyethylene glycol induced water stress on physiological and biochemical responses in Pigeon pea (Cajanus cajan L. Mill sp.). Recent Research in Science and Technology 3: 148-152.

Lannuci, A., M. Russo, L. Arena, N. D. Fonzo and P. Martiniello. 2002. Water deficit effect on osmotic adjustment and solute accumulation in leaves of annual clovers. European J. Agronomy 16: 111112.

Liu, H., X. Wang, D. Wang, Z. Zou and Z. Liang. 2011. Effect of drought stress on growth and accumulation of active constituents in Salvia miltorrhiza Bunge. Industrial Crops and Products 33:84-88

Ludlow, M. M. 1989. Strategies in Response to Water Stress. In. Kreeb HK, Rchter H, Hinckley TM. Ed. Structural and Functional Responses to Environmental Stresses: Water Shortage. The Hague, Netherlands. SPB Academic Press.

Qian, Y. and J. D. Fry. 1997. Water relation and drought tolerance of four Turfgrasses. J. Amer. Soc. Hort. Sci. 122(1):129-133.

Salwa, M. A and I. M. Heba. 2011. Alle- viation of adverse effects of droughtstress on common bean (Phaseolus vulgaris L) by exogenous application of hydrogen peroxide. Bangladesh J. Bot. 41(1): 75-83.

Sanchez, B. M. J., T. Fernandes, M. A. Morales, A. Morte and J. J. Alarcon. 2004. Variation in water status, gas exchange and growth in Rosmarinus officinalis plants infected with Glomus deserticola under drought conditions. J. Plant Physiol. 161: 675-682.

Slatyer, R. O. and H. D. Barrs. 1965. Modification to the relative turgidity technique with notes on significance as an index of the internal water status of leaves. Arid Zone Res. 25:331-342.

Steel, R. G. D dan J. H. Torrie. 1995. Prinsip dan Prosedur Statistika: Suatu Pendekatan Biometrik. Penerjemah Sumatri B. Jakarta: Gramedia. Terjemahan dari: Principles and Procedures of Statistics.

Taiz, L. and E. Zeiger. 2002. Plant Physiology. 3rd Ed.Sinauer Associates, Inc.

Uzilday, B., I. Turkan, A. H. Sekmen, R. Ozgur and H. C. Karakaya. 2012. Comparison of ROS formation and antioxidant enzymes in Cleome gynandra (C4) and C. spinosa (C3) under driught stress. Plant Science 182: $59-70$.

Yoshiba, Y., T. Kiyosue, K. Nakashima, K. Yamaguchi-Shinozaki, and K. Shinozaki. 1997. Regulation of levels of proline as an osmolyte in plants under water stress. Plant Cell Physiol. 38(10): 1095-1102

Zhou, X. B., L. Qi, G. M. Yang and Y. H. Chen. 2011. Row spacing effect on soil and leaf water status of summer soybean. The Journal of Animal Plant Science 21(4) : 680-685. 